\title{
Benign Cystic Mesothelioma in a Girl
}

\author{
Aditya Pratap Singh, ${ }^{1 *}$ Arun Kumar Gupta, ${ }^{1}$ Maryem Ansari, ${ }^{2}$ Dinesh Kumar Barolia, ${ }^{1}$ Vinay Mathur ${ }^{1}$
}

1 Department of Pediatric Surgery, SMS Medical College Jaipur, Rajasthan, India

2. Department of Pathology, SMS Medical College Jaipur, Rajasthan, India

\section{ABSTRACT}

Benign cystic mesothelioma (BCM) is an uncommon tumor. A 9-year-old girl presented with acute abdominal pain and vomiting for the last 24 hours. Ultrasound abdomen and contrast enhanced CT scan were suggestive of cystic lesion. At laparotomy, a cystic mass arising from the peritoneum was found, which was excised completely. On histopathological examination it was diagnosed as benign mesothelioma.

\section{Key words: Benign; Cystic; Child; Mesothelioma}

Correspondence*: Aditya Pratap Singh, Department of Pediatric Surgery, SMS Medical College Jaipur, Rajasthan, India.

E-mail:dr.adisms@gmail.com

Submitted: 23-06-2017

Conflict of Interest: None (c) 2017, Singh et al.

Accepted: 29-08-2017

Source of Support: Nil

This is an open-access article distributed under the terms of the Creative Commons Attribution License, which permits unrestricted use, distribution, and reproduction in any medium, provided the original work is properly cited.

\section{INTRODUCTION}

$\mathrm{BCM}$ of peritoneum is a rare tumor in children. It is commonly found in the pelvis of adult women.[1] It was first described in 1979 and few pediatric cases have been reported.[2,3] We here-in report another case of BCM which simulated mesenteric cyst preoperatively.

\section{CASE REPORT}

A 9-year-old girl, who had history of mild intermittent pain abdomen, presented with exacerbation of symptoms and vomiting for the last one day. On examination, there was tenderness in the right iliac region and an ill defined lump was palpated in lower abdomen (Fig.1). Routine blood investigations were within normal limits. Ultrasonography abdomen showed a large cystic mass, measuring $14 \times 5.6 \mathrm{~cm}$ in retroperitoneum and extending to the pelvis, suggestive of retroperitoneal cyst. CECT abdomen showed a cyst $15 \times 7 \mathrm{~cm}$ in size in right lumbar, epigastric, and umbilical regions. It was interpreted as mesenteric cyst (Fig.2).

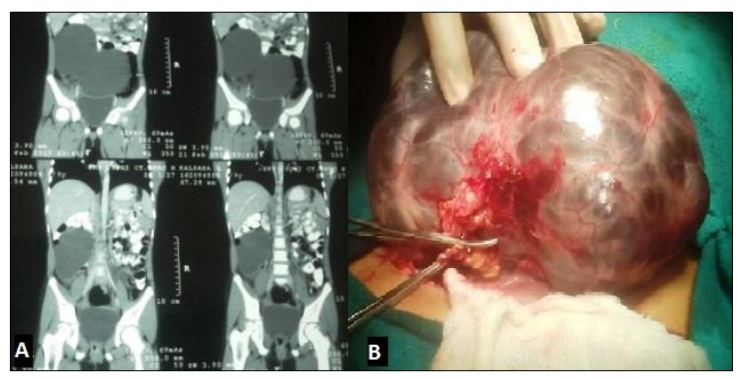

Figure 1: (A) CECT abdomen, (B) Peroperative picture.

At laparotomy, a cystic mass adherent to the transverse colon, omentum, and loops of the small bowel, was found (Fig.3). It was arising from the peritoneum. The lesion was carefully dissected out from the omentum and surfaces of small and large bowel. Histopathologic examination showed cyst lined by cuboidal hyperplastic mesothelial cells with underlying fibro-collagenous wall showing lymphocytic infiltrates. Attached omental tissue showed chronic inflammatory infiltrates. It was consistent with the diagnosis of benign mesothelioma. Immunohistochemistry confirmed it as BCM. Patient is on 
follow-up with no recurrence at 18 months after discharge.

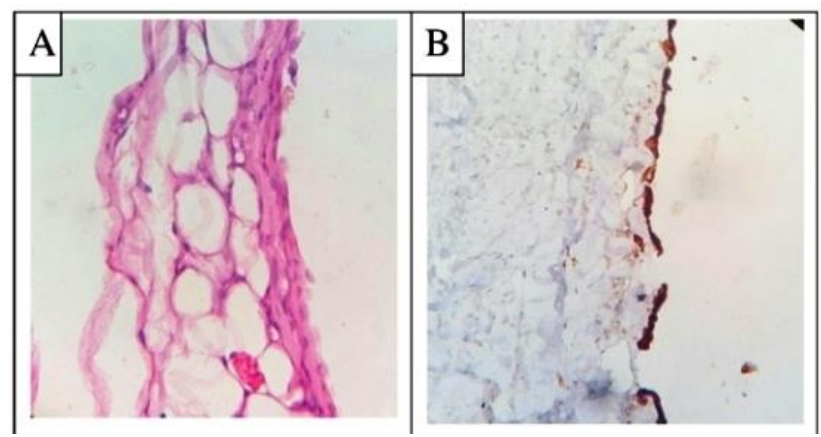

Figure 2: (A) Histopathological slide, (B) Immunohistochemistry showing calretinin positive slide

\section{DISCUSSION}

$\mathrm{BCM}$ of the peritoneum is a rare localized tumor arising from the epithelial and mesenchymal elements of the mesothelial cells.[1] Most commonly it arises from the pelvic retroperitoneum. BCM has mostly been described in women with a median age at presentation of 36 year.[1] Most BCMs are diagnosed incidentally, others present as a localized mass or abdominal pain.[4,5]

The preoperative diagnosis of benign cystic mesothelioma is difficult because of the nonspecific imaging. Based on its predominant multicystic nature, cystic lymphangiomatous malformation has been suggested as the leading alternate condition in the differential diagnosis. Similarly in the index case, the preoperative diagnosis was mesenteric cyst. Immunohistochemistry has been used in differentiation of this entity from a cystic lymphatic malformations of the abdomen.[3,6] The pathogenesis of $\mathrm{BCM}$ is also controversial, and thought to be a peritoneal response to chronic irritation or a developmental anomaly of the peritoneal layer.

The only effective treatment of BCM is complete excision of the cyst although recurrence is as high as $75 \% .[1,4]$
Other treatment methods used in adult patients are hormonal therapy, laser ablation, chemotherapy, and imageguided percutaneous drainage, and sclerotherapy.[7] Malignant transformation is rarely reported in literature.[5] To conclude, BCM should be kept in differential of cystic abdominal mass in children. Although rare, patients should be followed throughout life because of the risk of recurrence.

Consent: Authors have submitted signed consent form from legal guardians of the patient for use of clinical material in this manuscript. The Consent form is available with Editorial office.

Authors' Contribution: All authors contributed equally in concept, literature review, and drafting of the manuscript and approved the final version of this manuscript.

\section{REFERENCES}

1. Miles JM, Hart WR, McMahon JT. Cystic mesothelioma of the peritoneum. Report of a case with multiple recurrences and review of the literature. Clevel Clin Q. 1986; 53:109-14.

2. Tuncer AA, Narcı A, Dilek FH, Embleton DB, Çetinkurşun S. Benign cystic mesothelioma in a child: case report and review of the literature. Balkan Med J. 2016; 33:232-4.

3. Shakya VC, Agrawal CS, Karki S, Sah PL, Poudel P, Adhikary $\mathrm{S}$. Benign cystic mesothelioma of the peritoneum in a child-case report and review of the literature. J Pediatr Surg. 2011;46:23-6.

4. Raffat F, Egan M. Benign cystic mesothelioma of the peritoneum: immunohistochemical and ultrastructural features in a child. Pediatr Pathol. 1998; 8:321-9.

5. Safioleas MC, Constantinos K, Michael S, Konstantinos G, Constantinos S, Alkiviadis K. Benign multicystic peritoneal mesothelioma: a case report and review of the literature. World J Gastroenterol. 2006;12:5739-42.

6. Terry NZ, Fowler CL. Benign cystic mesothelioma in a child. J Pediatr Surg. 2009; 44:9-11.

7. Vallerie AM, Lerner JP, Wright JD, Baxi LV. Peritoneal inclusion cysts: a review. Obstet Gynecol Surv. 2009;64:321-34. 